\title{
Effect of soil and plant covering and sowing time on the yield of fennel bulbs grown from sowing directly in the field
}

\author{
Marzena Błażewicz-Woźniak \\ Department of Soil Cultivation and Fertilization of Horticultural Plants \\ University of Life Sciences in Lublin \\ Leszczyńskiego 58, 20-068 Lublin, Poland \\ e-mail: marzena.wozniak@up.lublin.pl
}

\begin{abstract}
A field experiment on fennel growing (Foeniculum vulgare var. azoricum Mill.) was conducted at the Experimental Farm of the University of Life Sciences in Lublin, on a grey-brown podzolic soil. The experiment included the following factors: three kinds of covers - soil covering with black polyethylene film (PE $0.05 \mathrm{~mm}$ ), soil covering with black polypropylene non-woven fabric (PP $50 \mathrm{~g} \mathrm{~m}^{-2}$ ) and flat covering of plants with white polypropylene non-woven fabric (PP $17 \mathrm{~g} \mathrm{~m}^{-2}$ ); three sowing terms - April, May, June; two fennel cultivars - 'Rudy $F_{1}$ ' and 'Zefa Fino'. Soil mulching with PP50 and, to a slightly lesser degree, black PE, caused an increase in the total and marketable yield of fennel bulbs and had a favourable effect on the yield structure. The lowest yield, with the highest share of non-marketable bulbs, was obtained following plant covering with PP17. The bulbs were the largest in the experimental treatments with PP50 mulching. The smallest bulbs were harvested following PP17 plant covering. For fennel growing, the most favourable sowing time was April. The lowest yield was obtained from the June sowings. The cultivars studied did not vary in terms of yield level and structure. The bulbs of the 'Zefa Fino' cultivar were longer and more slender than those of the 'Rudy $F_{1}$ ' cultivar.
\end{abstract}

Key words: black film, cultivars, Foeniculum vulgare, non-woven fabric, quality of bulbs, yield

\section{INTRODUCTION}

Fennel (Foeniculum vulgare var. azoricum Mill.) is a vegetable that is not commonly grown in Poland in spite of its high dietary value (Atta-Aly et al. 1999, Wierzbicka 2002, Koudela and Petř́ková 2008). Fennel bulbs that find their way onto the Polish market are imported from Italy and Spain. Fennel is mostly grown in southern Europe, due to the favourable climatic conditions, and it is also increasingly common in the USA, Germany, Holland and Belgium (Morales et al. 1993, Behrendt 2001, Mencarelli 2004). Fennel yields well in a Mediterranean climate, with gentle winters and hot summers (Carrubba et al. 2002). In the conditions of Poland, fennel cultivation is recommended for early spring, from covered seedlings, or from sowing in the soil from June till mid-July, due to the fact that plants sown earlier tend to bloom (Plucińska 2001, Wierzbicka 2002). The objective of the study reported here was to determine the effect of soil and plant covering on the yield of fennel bulbs, and to identify the optimum time of growing fennel from direct sowing in the field.

\section{MATERIAL AND METHODS}

The field experiment was conducted in the years 1998-2000, at the Felin Experimental Farm of the University of Life Sciences in Lublin $\left(51^{\circ} 23^{\prime} \mathrm{N}\right.$, $22^{\circ} 56^{\prime} \mathrm{E}$ ), on a grey-brown podzolic soil developed from loess formations overlying chalk marls, with 
Table 1. Timetable of significant treatments in fennel cultivation in the years 1998-2000

\begin{tabular}{|c|c|c|c|c|c|c|c|}
\hline \multirow{2}{*}{ Year } & \multirow{2}{*}{ Sowing date } & \multicolumn{2}{|c|}{$\begin{array}{c}\text { Beginning } \\
\text { of emergence }\end{array}$} & \multicolumn{2}{|c|}{ Removal of PP17 } & \multicolumn{2}{|c|}{ Harvest } \\
\hline & & $\mathrm{A}$ & $\mathrm{B}$ & A & $\mathrm{B}$ & A & $\mathrm{B}$ \\
\hline \multirow{3}{*}{1998} & I - 6.05 & 16.05 . & 10 & 6.07 & 61 & 7.08. & 92 \\
\hline & II - 27.05. & 10.06 . & 12 & 21.07. & 57 & 21.08 . & 87 \\
\hline & III - 17.06. & 30.06. & 13 & 11.08. & 55 & 2.09 . & 76 \\
\hline \multirow{3}{*}{1999} & I - 27.04 & 10.05 . & 12 & 8.06 & 41 & 20.07 . & 83 \\
\hline & II - 26.05. & 10.06 & 13 & 8.07 & 41 & 16.08 . & 80 \\
\hline & III - 22.06. & 3.07. & 11 & 15.08. & 53 & 9.09. & 78 \\
\hline \multirow{3}{*}{2000} & I - 26.04. & 10.05 . & 13 & 12.06. & 46 & 19.07. & 85 \\
\hline & II - 24.05. & 9.06 & 15 & 19.07. & 55 & 16.08 . & 83 \\
\hline & III - 21.06. & 4.07. & 12 & 7.08 & 46 & 5.09 & 75 \\
\hline
\end{tabular}

A - Date; B - Days after sowing

a grain size composition corresponding to that of weak silty loams. The crop plant in the experiment was fennel (Foeniculum vulgare var. azoricum Mill.). The experiment was set up using the method of fully randomised blocks, in four replications. The surface area of a plot for harvest was $3.2 \mathrm{~m}^{2}$. The experiment included the following factors: three kinds of covers - soil covering with black polyethylene film (PE $0.05 \mathrm{~mm}$ ), soil covering with black polypropylene non-woven fabric (PP $50 \mathrm{~g} \mathrm{~m}^{-2}$ ) and flat covering of plants with white polypropylene non-woven fabric (PP $17 \mathrm{~g} \mathrm{~m}^{-2}$ ) and a control treatment (no cover); three sowing terms - April, May, June (Tab. 1); two fennel cultivars - 'Rudy F' ' and 'Zefa Fino'.

The forecrop for the fennel was white cabbage. Tillage included deep ploughing before winter, with harrowing in spring, followed by cultivating and finishing tillage. Pre-sowing fertilisation was applied as follows: $80 \mathrm{~kg} \mathrm{~N}$ (ammonium nitrate), $35.2 \mathrm{~kg} \mathrm{P}$ (triple superphosphate) and $91.3 \mathrm{~kg}$ $\mathrm{K}$ (potash salt) per 1 ha. Weeding was done by hand. Anti-aphid spraying with a Pirimor 50DP preparation was conducted as required. Fennel seeds were sown in rows, two seeds per point, at $20 \mathrm{~cm}$ spacing in the rows. Row spacing was $40 \mathrm{~cm}$. After the plants produced two proper leaves, thinning was made, leaving a single plant per point. The times of the agronomic treatments and observations in the fennel culture are given in Table 1.

The crop was harvested once, when most of the bulbs reached a mass of $\geq 200 \mathrm{~g}$, accepting that as the minimum for marketable bulbs (Vogel 1987, Vanparys 1999 a, b, Damato 2000, Cserni and Kovács 2002, Wierzbicka 2002). Determinations were made of the yield level and structure: class I, class II, out of selection (UNECE 2005), and of the mean weight of fennel bulbs in the particular selections. Bulb dimensions were measured (height, width, thickness, shape factor). The obtained results were processed statistically using the method of analysis of variance. The significance of differences was determined by means of Tukey's intervals of confidence at a significance level of $\mathrm{p}=0.05$.

\section{RESULTS}

The mean total yield of fennel bulbs over the threeyear period of the experiment was $23.9 \mathrm{t} \mathrm{ha}^{-1}$, of which the marketable yield was $17.8 \mathrm{t} \mathrm{ha}^{-1}$ (Tab. 2).

Based on the obtained results, the times of sowing and the covering applied had the same effect on the total and marketable yields of fennel bulbs. Soil mulching caused an increase in the bulb yield, though the differences were not statistically significant compared to the control. Significantly the lowest yield of bulbs was obtained after plant covering with non-woven fabric PP17 (mean of $17.0 \mathrm{t} \mathrm{ha}^{-1}$, out of which $11.4 \mathrm{t} \mathrm{ha}^{-1}$ was marketable yield). The highest total yield $\left(27.4 \mathrm{t} \mathrm{ha}^{-1}\right)$ was harvested from plots covered with black non-woven fabric PP50, and the highest marketable yield resulted from soil mulching with black PE film (20.5 $\left.\mathrm{t} \mathrm{ha}^{-1}\right)$. The plants harvested from the April sowings had the best yielding. Fennel sown in April gave the significantly highest total yield $\left(35.2 \mathrm{tha}^{-1}\right)$ and marketable yield $\left(27.1 \mathrm{t} \mathrm{ha}^{-1}\right)$ of bulbs. The lowest yields, in all of the years of the experiment, were obtained from the June sowings (13.2 and $9.0 \mathrm{t} \mathrm{ha}^{-1}$, respectively). No significant differences in the total and marketable yields were observed between the cultivars studied. Both cultivars showed similar responses to the experimental factors.

Bulbs of class I constituted, on average, 36.4\% of the total yield of fennel bulbs (Fig. 1).

The highest share of class I bulbs in the total yield was obtained from plots mulched with black PE film (43.5\%), and the lowest from those 
Table 2. Effect of covering and sowing date on the total and marketable yields of fennel (mean for the years 1998-2000)

\begin{tabular}{|c|c|c|c|c|c|c|c|c|}
\hline \multirow{3}{*}{ Kind of covering } & \multicolumn{4}{|c|}{ Total yield $\left(\mathrm{t} \mathrm{ha}^{-1}\right)$} & \multicolumn{4}{|c|}{ Marketable yield $\left(\mathrm{t} \mathrm{ha}^{-1}\right)$} \\
\hline & \multicolumn{8}{|c|}{ Month of sowing } \\
\hline & IV & $\mathrm{V}$ & $\mathrm{VI}$ & Mean & IV & $\mathrm{V}$ & VI & Mean \\
\hline & \multicolumn{8}{|c|}{ 'Rudy $\mathrm{F}_{1}$ ' cultivar } \\
\hline Control & 34.0 & 27.3 & 10.8 & 24.0 & 27.6 & 21.9 & 8.8 & 19.4 \\
\hline $\mathrm{PE}$ & 34.2 & 28.4 & 14.7 & 25.8 & 25.3 & 22.5 & 11.4 & 19.7 \\
\hline PP50 & 41.0 & 25.8 & 17.0 & 27.9 & 32.9 & 17.4 & 14.0 & 21.4 \\
\hline PP17 & 28.9 & 15.0 & 4.2 & 16.0 & 22.3 & 9.3 & 0.5 & 10.7 \\
\hline \multirow[t]{2}{*}{ Mean } & 34.5 & 24.1 & 11.7 & 23.4 & 27.0 & 17.8 & 8.7 & 17.8 \\
\hline & \multicolumn{8}{|c|}{ 'Zefa Fino' cultivar } \\
\hline Control & 33.1 & 27.4 & 13.8 & 24.8 & 24.9 & 24.0 & 9.6 & 19.5 \\
\hline $\mathrm{PE}$ & 38.8 & 29.6 & 15.5 & 28.0 & 28.9 & 22.3 & 12.4 & 21.2 \\
\hline PP50 & 37.6 & 20.4 & 22.6 & 26.8 & 29.1 & 13.7 & 12.5 & 18.4 \\
\hline PP17 & 33.8 & 13.2 & 6.9 & 17.9 & 26.0 & 7.8 & 2.4 & 12.1 \\
\hline \multirow[t]{2}{*}{ Mean } & 35.8 & 22.7 & 14.7 & 24.4 & 27.2 & 16.9 & 9.2 & 17.8 \\
\hline & \multicolumn{8}{|c|}{ Mean } \\
\hline Control & 33.5 & 27.3 & 12.3 & 24.4 & 26.3 & 23.0 & 9.2 & 19.5 \\
\hline $\mathrm{PE}$ & 36.5 & 29.0 & 15.1 & 26.9 & 27.1 & 22.4 & 11.9 & 20.5 \\
\hline PP50 & 39.3 & 23.1 & 19.8 & 27.4 & 31.0 & 15.6 & 13.3 & 19.9 \\
\hline PP17 & 31.4 & 14.1 & 5.6 & 17.0 & 24.2 & 8.6 & 1.5 & 11.4 \\
\hline Mean & 35.2 & 23.4 & 13.2 & 23.9 & 27.1 & 17.4 & 9.0 & 17.8 \\
\hline \multirow{3}{*}{$\begin{aligned} \mathrm{LSD}_{0.05} \text { for: } & \text { coverings } \\
& \text { sowing dates } \\
& \text { cultivars }\end{aligned}$} & & & & 4.12 & & & & 3.95 \\
\hline & & & & 3.25 & & & & 3.11 \\
\hline & & & & n.s. & & & & n.s. \\
\hline
\end{tabular}

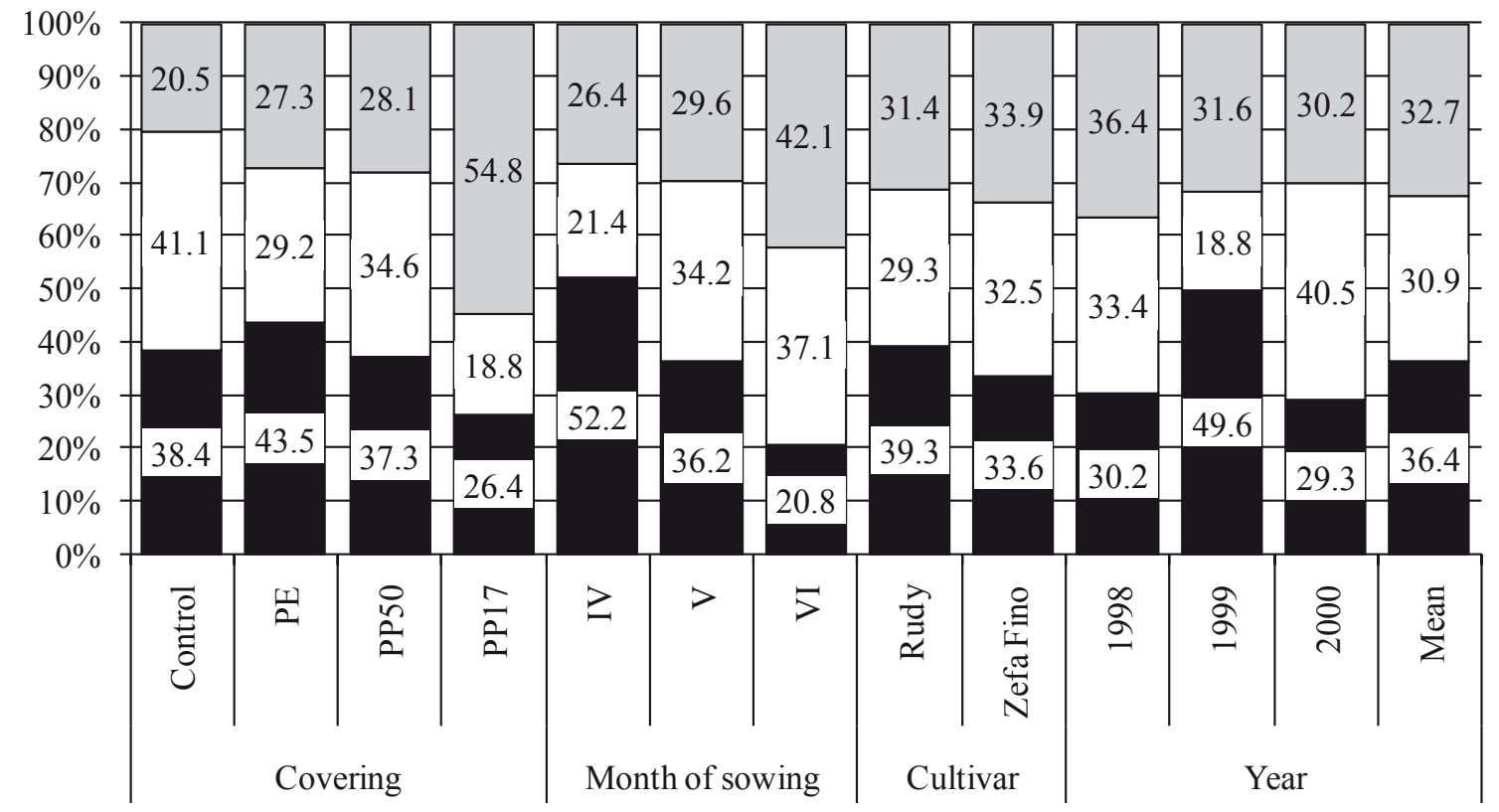

I Class $\square$ II Class $\quad \square$ Unmarketable

Figure 1. Effect of covering and sowing date on the yield structure of fennel bulbs in 1998-2000 
covered with PP17 non-woven fabric (26.4\%). The covering of plants with PP17 non-woven fabric caused an increase in the share of non-marketable bulbs in the yield (54.8\%), relative to the remaining experimental treatments. The unfavourable effect of plant covering was especially observable for the latest sowing time, in June, when the harvest from those plots contained as much as $86.4 \%$ of bulbs out of selection. As a result, the June sowing produced the lowest share of marketable yield. The highest share of class I bulbs in the yield was recorded for the April sowings (52.2\%), and the lowest from the June ones (20.8\%). 'Rudy $\mathrm{F}_{1}$ ' bulbs of class I constituted on average $39.3 \%$ of the yield. The 'Rudy $\mathrm{F}_{1}$ ' cultivar dominated in terms of that trait over 'Zefa Fino' (33.6\%), though the share of marketable bulbs in the yield of the two cultivars did not differ significantly. No differences were found for that trait between the years of the experiment, either.

Soil mulching with PP50 black non-woven fabric caused an increase in the weight (up to $357 \mathrm{~g}$, on average) and dimensions of fennel bulbs compared to the other experimental treatments (Tabs 3 and 4).
Bulbs from plots mulched with black non-woven fabric were the largest, though the differences were not significant relative to the control. Significantly, the smallest bulbs, with the lowest weight (mean of $210 \mathrm{~g}$ ) and the lowest values of height, width and thickness, were obtained from the plots that were covered with PP17 non-woven fabric. Only for the first sowing, in April, no negative effects of plant covering with PP17 on the shape parameters of the bulbs were observed. The analysis of fennel yields permitted the conclusion that the non-marketable yield from the mulched treatments was dominated by large, overgrown and cracked bulbs, while the yield from plots mulched with PP17 contained a lot of small bulbs, with weights below $100 \mathrm{~g}$.

The fennel bulbs sown in April were characterised by the greatest weight (mean of $349 \mathrm{~g}$ ) compared to the other sowing times (Tab. 3). They were also the longest and the widest compared to bulbs of plants from later sowing dates (Tab. 4). The lowest weight at the time of harvest was that of fennel bulbs from the June sowings ( $259 \mathrm{~g}$ ). In addition, the marketable bulbs from sowings made in April were the largest, and their average weight was $374 \mathrm{~g}$. The cultivars

Table 3. Effect of covering and sowing date on the mean weight of fennel bulbs (mean for the years 1998-2000)

\begin{tabular}{|c|c|c|c|c|c|c|c|c|}
\hline \multirow{3}{*}{ Kind of covering } & \multicolumn{4}{|c|}{ Mean weight of bulb (g) } & \multicolumn{4}{|c|}{ Weight of marketable bulb (g) } \\
\hline & \multicolumn{8}{|c|}{ Month of sowing } \\
\hline & IV & $\mathrm{V}$ & VI & Mean & IV & $\mathrm{V}$ & VI & Mean \\
\hline & \multicolumn{8}{|c|}{ 'Rudy $F_{1}^{\prime}$ cultivar } \\
\hline Control & 347 & 347 & 284 & 326 & 370 & 363 & 333 & 355 \\
\hline $\mathrm{PE}$ & 342 & 343 & 293 & 326 & 374 & 363 & 328 & 355 \\
\hline PP50 & 379 & 312 & 371 & 354 & 416 & 312 & 356 & 362 \\
\hline PP17 & 292 & 191 & 86 & 190 & 308 & 277 & 340 & 308 \\
\hline \multirow[t]{2}{*}{ Mean } & 340 & 298 & 259 & 299 & 367 & 329 & 339 & 345 \\
\hline & \multicolumn{8}{|c|}{ 'Zefa Fino' cultivar } \\
\hline Control & 353 & 364 & 269 & 329 & 357 & 400 & 339 & 365 \\
\hline $\mathrm{PE}$ & 349 & 354 & 238 & 314 & 387 & 360 & 302 & 350 \\
\hline PP50 & 378 & 297 & 404 & 360 & 419 & 320 & 441 & 393 \\
\hline PP17 & 350 & 219 & 122 & 230 & 365 & 269 & 243 & 292 \\
\hline \multirow[t]{2}{*}{ Mean } & 358 & 309 & 258 & 308 & 382 & 337 & 331 & 350 \\
\hline & \multicolumn{8}{|c|}{ Mean } \\
\hline Control & 350 & 356 & 277 & 328 & 364 & 382 & 336 & 360 \\
\hline $\mathrm{PE}$ & 346 & 349 & 266 & 320 & 381 & 362 & 315 & 353 \\
\hline PP50 & 379 & 305 & 388 & 357 & 418 & 316 & 399 & 377 \\
\hline PP17 & 321 & 205 & 104 & 210 & 337 & 273 & 292 & 300 \\
\hline Mean & 349 & 304 & 259 & 304 & 374 & 333 & 336 & 348 \\
\hline \multirow{3}{*}{$\begin{aligned} \mathrm{LSD}_{0.05} \text { for: } & \text { coverings } \\
& \text { sowing dates } \\
& \text { cultivars }\end{aligned}$} & & & & 35.2 & & & & 42.2 \\
\hline & & & & 27.8 & & & & 32.8 \\
\hline & & & & n.s. & & & & n.s. \\
\hline
\end{tabular}


Table 4. Effect of covering and sowing date on some properties of the shape of fennel bulbs (mean from 1998-2000)

\begin{tabular}{|c|c|c|c|c|c|c|c|c|c|c|c|c|c|c|c|c|}
\hline \multirow{3}{*}{$\begin{array}{l}\text { Kind of } \\
\text { covering }\end{array}$} & \multicolumn{4}{|c|}{$\begin{array}{l}\text { Height of bulb } \\
(\mathrm{mm})\end{array}$} & \multicolumn{4}{|c|}{$\begin{array}{c}\text { Diameter of bulb } \\
(\mathrm{mm})\end{array}$} & \multicolumn{4}{|c|}{$\begin{array}{l}\text { Thickness } \\
(\mathrm{mm})\end{array}$} & \multicolumn{4}{|c|}{ Coefficient of shape } \\
\hline & \multicolumn{16}{|c|}{ Month of sowing } \\
\hline & IV & $\mathrm{V}$ & VI & Mean & IV & V & VI & Mean & IV & V & VI & Mean & IV & V & VI & Mean \\
\hline & \multicolumn{16}{|c|}{ 'Rudy $F_{1}$ ' Cultivar } \\
\hline Control & 121 & 114 & 103 & 113 & 115 & 115 & 108 & 113 & 55 & 59 & 60 & 58 & 1.05 & 1.00 & 0.97 & 1.01 \\
\hline PE & 123 & 113 & 101 & 112 & 118 & 114 & 113 & 115 & 56 & 60 & 62 & 59 & 1.04 & 1.00 & 0.90 & 0.98 \\
\hline PP50 & 129 & 111 & 103 & 114 & 124 & 112 & 110 & 116 & 60 & 57 & 62 & 60 & 1.04 & 0.99 & 0.94 & 0.99 \\
\hline PP17 & 123 & 112 & 93 & 109 & 110 & 101 & 93 & 102 & 53 & 53 & 46 & 51 & 1.14 & 1.11 & 1.00 & 1.09 \\
\hline \multirow[t]{2}{*}{ Mean } & 124 & 113 & 100 & 112 & 117 & 111 & 106 & 111 & 56 & 57 & 58 & 57 & 1.07 & 1.03 & 0.95 & 1.02 \\
\hline & \multicolumn{16}{|c|}{ 'Zefa Fino' cultivar } \\
\hline Control & 129 & 125 & 101 & 118 & 116 & 117 & 111 & 115 & 57 & 66 & 60 & 61 & 1.12 & 1.08 & 0.93 & 1.04 \\
\hline PE & 131 & 117 & 102 & 117 & 118 & 116 & 105 & 113 & 57 & 61 & 57 & 58 & 1.12 & 1.02 & 0.98 & 1.04 \\
\hline PP50 & 144 & 119 & 114 & 126 & 119 & 108 & 125 & 117 & 59 & 58 & 68 & 62 & 1.22 & 1.12 & 0.92 & 1.09 \\
\hline PP17 & 125 & 109 & 95 & 110 & 118 & 93 & 94 & 102 & 57 & 55 & 46 & 53 & 1.07 & 1.19 & 1.03 & 1.10 \\
\hline \multirow[t]{2}{*}{ Mean } & 132 & 118 & 103 & 118 & 118 & 108 & 109 & 112 & 57 & 60 & 58 & 58 & 1.13 & 1.10 & 0.96 & 1.07 \\
\hline & \multicolumn{16}{|c|}{ Mean } \\
\hline Control & 125 & 120 & 102 & 116 & 115 & 116 & 110 & 114 & 56 & 63 & 60 & 60 & 1.09 & 1.04 & 0.95 & 1.03 \\
\hline $\mathrm{PE}$ & 127 & 115 & 102 & 115 & 118 & 115 & 109 & 114 & 56 & 61 & 60 & 59 & 1.08 & 1.01 & 0.94 & 1.01 \\
\hline PP50 & 137 & 115 & 109 & 120 & 122 & 110 & 118 & 116 & 59 & 58 & 65 & 61 & 1.13 & 1.06 & 0.93 & 1.04 \\
\hline PP17 & 124 & 110 & 94 & 110 & 114 & 97 & 94 & 102 & 55 & 54 & 46 & 52 & 1.11 & 1.15 & 1.01 & 1.09 \\
\hline Mean & 128 & 116 & 102 & 115 & 117 & 110 & 107 & 111 & 57 & 59 & 58 & 58 & 1.10 & 1.07 & 0.96 & 1.04 \\
\hline \multirow{3}{*}{\multicolumn{3}{|c|}{$\begin{aligned} \mathrm{LSD}_{0.05} \text { for: } & \text { coverings } \\
& \text { sowing dates } \\
& \text { cultivars }\end{aligned}$}} & & 5.9 & & & & 6.3 & & & & 4.9 & & & & 0.05 \\
\hline & & & & 4.6 & & & & 4.9 & & & & n.s. & & & & 0.04 \\
\hline & & & & 3.0 & & & & n.s. & & & & n.s. & & & & 0.02 \\
\hline
\end{tabular}

studied did not differ significantly in terms of the weight of bulbs and of marketable bulbs. Bulbs of the 'Zefa Fino' cultivar were significantly longer and more slender than those of 'Rudy F' (Tab. 4).

\section{DISCUSSION}

The study presented here demonstrated that the best of the compared mulches in the cultivation of fennel was the PP50 black non-woven fabric, while direct covering of plants with PP17 nonwoven fabric can only be applied in very early cultivation. The plots with black non-woven fabric mulching produced the highest total yield, and the bulbs had the greatest weight and dimensions. Soil mulching with the black PE film had a favourable effect on yield structure, causing an increase in the share of class I bulbs in the total yield. Also, in the cultivation of garlic the application of soil mulching with black PE film had a positive effect on the total and marketable yield and on the quality traits of bulbs (Rekowska 1997). In a study by Najda (2004), celery grew better on soil mulched with black film than with black non-woven fabric, but the total and marketable yields were similar following both mulches. Soil covering with a mulch of black PE film or with PP50 non-woven fabric ensured better thermal and water conditions than the non-covered soil in the control treatment. The mulches applied caused a significant increase in soil temperature compared to the non-covered soil, and soil mulching with black PE film and PP50 non-woven fabric reduced the diurnal variations in soil temperature (Błażewicz-Woźniak 2006). A similar opinion was expressed by Siwek and Libik (2005), who attributed the superior growth of plants mulched with black PE film to higher and more uniform soil moisture content. As a result, in the treatments mulched with PP50 non-woven fabric the plants grew the fastest and attained the largest dimensions and weight at the time of harvest. In the cultivation of zucchini, soil covering with black non-woven fabric increased the share of marketable yield compared to black film mulching, while the film accelerated the early harvest to a greater degree than the non-woven fabric did (Kołota and Słociak 2003). According to Buczkowska (1996), 
an increase in soil temperature under black film mulch had a decisive effect on the yield of peppers.

In the experiment reported here, the plots covered with PP17 non-woven fabric produced the lowest total and marketable yields of fennel, and the bulbs were the smallest. Only for the first sowing time, i.e. April, the negative effect of plant covering with PP17 was not significant. It is to be assumed that for the later sowing times the application of that covering created unfavourable conditions for the formation of bulbs. Excessive temperatures and limited access of light disturbed the growth of plants under PP17 non-woven fabric. Kuskowska and Wierzbicka (2000) reported lower marketable yields of cucumber mulched with PP non-woven fabric compared to that grown in soil mulched with black PE film. Krężel and Kołota (2000) demonstrated that the application of nonwoven fabric covering and perforated film in the cultivation of beetroot is justified only for very early sowing dates. In a study by Benoit and Ceustermans (1994), fennel yielded better under a mulch of non-woven fabric (Agryl) than of perforated foil (Pervistal). Dobromilska (2000) obtained the highest total yield of fennel bulbs grown under a covering of PP17 non-woven fabric from seedlings sown in March. Rekowska and Słodkowski (2005) also recorded a favourable effect of plant covering with PP non-woven fabric on the yielding of corn salad only in the case of an earlier time of harvest (3.06); when harvest time was delayed by two weeks, the effect of the PP mulching, compared to a non-covered field, disappeared. Kalisz and Cebula (2001) demonstrated that polypropylene non-woven fabric and perforated foil covering applied until the $14^{\text {th }}$ May had a favourable effect on Chinese cabbage yielding compared to a non-mulched control. Wierzbicka (1999) observed that the effect of the application of mulches in the cultivation of lettuce depended on the weather conditions. In a year with a cool spring, early covering of the soil with black film did not accelerate the lettuce harvest and caused a slight decrease in yields, while with a warm spring better results were obtained when black film mulching was applied, the best yields being produced by lettuce covered with PP nonwoven fabric.

In our study, the optimum sowing time for fennel was April. Plants sown at that time produced the highest total and marketable yields. Fennel bulbs from plants sown in April were the largest. The lowest marketable yields were obtained for plants sown in June, which also had the smallest bulbs.
Similar results were obtained by Dobromilska (1999). However, the results of this study did not support those obtained by Błażewicz-Woźniak et al. (1997) in 1996, when the best date for sowing in the field was the $21^{\text {st }}$ of June. In turn, in a study on fennel cultivation conducted in the years 2001-2003, the highest total yield was obtained from sowings made on the $20^{\text {th }}$ of May and the lowest from April, while the highest marketable yield was obtained from June sowings, with notable differences between the years of the study (Błażewicz-Woźniak 2006). That was due undoubtedly to the varied weather conditions. The yielding of vegetables is largely dependent not only on the sum of precipitation during the vegetation period, but first of all on its distribution during the vegetation of the plants. Many researchers acknowledge the effect of the weather on variability in the response of vegetable crops to experimental factors in particular years of experiments (Vanparys 1999 a, b, Wierzbicka 1999, Rusch 2001, Kalisz 2005, Michalik and Szweykowska 2005, Siwek and Libik 2005, Abou El-Magd et al. 2008). The yields of fennel obtained in our experiment, as well as the studied features of the bulbs (weight, height, width, thickness), did not differ much from results obtained by other researchers (Morales et al. 1993, Damato 2000, Atta-Aly 2001, Koudela and Petř́ková 2008).

The cultivation times of a given species depend not only on climatic conditions but also on the cultivars, and in the case of fennel also on the photoperiodic response of cultivars and their tendency to create bolters (Vanparys 1999 a, b, AttaAly 2001, Abou El-Magd et al. 2008). In the study, the author made a comparison of yielding of two fennel cultivars - 'Rudy $F_{1}$ ' and 'Zefa Fino' - that in earlier experiments had given the highest yields among 11 cultivars tested (Błażewicz-Woźniak et al. 1997). Both cultivars displayed similar responses to the experimental factors and no significant differences were noted in their yield, with the mean marketable yield for the three-year period of the study being the same, at $17.8 \mathrm{t} \mathrm{ha}^{-1}$. The cultivars also did not differ in terms of the average weight of bulbs and of the weight of marketable bulbs. 'Zefa Fino' bulbs were longer and more slender than those of 'Rudy $F_{1}$ ', which was due to the cultivar-related features of the species. In a study by Koudela and Petříková (2008), 'Zefa Fino' showed a significantly higher average yield in the summer sowing times and 'Rudy $\mathrm{F}_{1}$ ' in the autumn ones. In the experiments conducted by Vanparys (1999 a), the 'Zefa Fino', 'Argo' and 'Atos' cultivars had the 
highest yields when the sowing was done in March and the harvest in July. The yielding of 'Rudy' varied in the successive years of the experiments. In a study conducted by Dobromilska (1999) in Pomerania, 'Rudy $\mathrm{F}_{1}$ ' gave better yields than 'Zefa Fino' in April sowings in the field. Morales et al. (1993), comparing the yielding of 16 cultivars of Foeniculum vulgare var. azoricum, obtained the highest yield, and the best in terms of quality, for the cultivar 'Zefa Fino', which produced the largest bulbs. Numerous studies confirm the universal character of 'Zefa Fino' and its good yielding at various cultivation times (Vogel 1987, Benoit and Ceustermans 1998, Vanparys 1999 a, Dimson and Agnew 2001). Our study demonstrated a high suitability of both cultivars tested, i.e. 'Rudy $\mathrm{F}_{1}$ ' and 'Zefa Fino', for cultivation in the region of central-eastern Poland.

\section{CONCLUSIONS}

1. Soil mulching with PP50 black non-woven fabric and, to a slightly lesser extent, black PE film, caused an increase of the total and marketable yield of fennel and had a favourable effect on its structure. The lowest total yield of bulbs with the highest share of non-marketable yield was obtained after plant covering with PP17 nonwoven fabric.

2. The fennel bulbs obtained from plots with PP50 non-woven fabric mulching had the greatest weight and dimensions. The smallest bulbs were obtained following plant covering with PP17 non-woven fabric.

3. April sowing was the most favourable for fennel. Plants sown in April produced the highest total and marketable yields of bulbs, and the bulbs had the greatest weight. The lowest yields were obtained from the June sowings.

4. The cultivars studied did not differ in terms of yield level and structure. 'Zefa Fino' fennel bulbs were longer and more slender than 'Rudy $F_{1}$ '.

\section{REFERENCES}

Abou El-Magd M.M., Zaki M.F., Abou-Hussein S.D., 2008. Effect of organic manure and different levels of saline irrigation water on growth, green yield and chemical content of sweet fennel. Austral. J. Basic Appl. Sci. 2(1): 90-98.

Atta-Aly M.A., 2001. Fennel swollen base yield and quality as affected by variety and source of nitrogen fertilizer. Sci. Hort. 88(3): 191-202.
Atta-Aly M.A., Khattab M.E., El-S Lacheene Z., AbDallah M.M.F., 1999. Fennel production as a new vegetable and aromatic crop in Egypt. I. Variety and planting distance impacts on swollen base yield, quality and essential oil content and constituents. Arab. Univ. J. Agric. Sci. 7(1): 203-221.

Behrendt S., 2001. Die kleine Markstudie, Knollenfenchel. Gemüse München 37: 47-49.

Benoit F., Ceustermans N., 1994. Use of plastic for Florence fennel in the spring. Eur. Veg. Res. Dev. Cent.: 65-70.

Benoit F., Ceustermans N., 1998. Plastic. New developments in direct covering of bulb fennel. Proeftuin. 8(7): 36-37.

BŁażeWicz-WoźniaK M., 2006. The effect of agrotechnical factors on the growth and yielding of fennel (Foeniculum vulgare var. azoricum Mill.). Rozpr. Nauk. AR w Lublinie 314: 134.

BŁażewicz-Woźniak M., KęsiK T., Bednarz E., 1997. Porównanie plonowania kilku odmian kopru włoskiego (Foeniculum vulgare Mill. var. azoricum Thell.) w warunkach Lubelszczyzny. Mat. VII Zjazdu Hod. Rośl. Ogrodn. „Hodowla, nasiennictwo i szkółkarstwo roślin ogrodniczych o podwyższonej jakości”, 11-13 września, Szczecin: 349-352.

Buczkowska H., 1996. Badania nad modyfikacją mikroklimatu w polowej uprawie papryki słodkiej (Capsicum annuum L.). Rozpr. Nauk. AR w Lublinie 197: 73.

Carrubba A., La Torre R., Matranga A., 2002. Cultivation trials of some aromatic and medicinal plants in a semi-arid Mediterranean environment. Acta Hort. 576: 207-213.

CSERni I., KovÁcs N., 2002. A gumós édeskömény (Foeniculum vulgare Mill. convar. azoricum Mill. Thell.) termeszthetősége Magyarországon. Acta Agraria Debreceniensis 9: 3 .

Damato G., 2000. Seed production methods and yield characteristics of Florence fennel heads (Foeniculum vulgare Mill. var. azoricum Thell.). Acta Hort. 533: 59-65.

Dimson E.V., Agnew K., 2001. Crop profile for fennel in Arizona. West. Grow. Assoc. Phoenix, Univ. Arizona: 18.

DoBromilsKA R., 1999. Ocena wartości biologicznej fenkuła w zależności od warunków uprawy. Zesz. Probl. Post. Nauk Roln. 466: 227-236.

Dobromilska R., 2000. Effect of growing place on growth and development of two fennel cultivars. Part II. Plant yield. Umbell. Improv. New. 10: 33-35.

Kalisz A., 2005. Przydatność wybranych odmian kapusty pekińskiej (Brassica pekinensis Rupr.) do uprawy wiosennej. Zesz. Nauk. AR we Wrocławiu, LXXXVI, 515: 223-229.

Kalisz A., Cebula S., 2001. Direct plant covering and soil mulching in the spring production of some Chinese cabbage cultivars. Growth and yielding. 
Effect of temperature on premature bolting. Folia Hort. 13(1-2): 3-22.

Koєota E., SŁociak A., 2003. The effects of the term of weed removal and soil mulching on yield and chemical composition of zucchini fruits. Veg. Crops Res. Bull. 59: 83-89.

Koudela M., Petříková K., 2008. Nutritional compositions and yield of sweet fennel cultivars Foeniculum vulgare Mill. ssp. vulgare var. azoricum (Mill.) Thell. Hort. Sci. 35(1): 1-6.

Krężel J., Kołota E., 2000. Wpływ odmiany, terminu siewu nasion i osłaniania roślin na plonowanie buraka ćwikłowego w uprawie na zbiór pęczkowy. Ann. Univ. M. Curie-Skłodowska, Sect. EEE, Suppl. 8: 219-226.

Kuskowska M., WierzBicka B., 2000. Wpływ metod uprawy na plonowanie odmian ogórka polowego. Ann. Univ. M. Curie-Skłodowska, Sect. EEE, Suppl. 8: 399-404.

Mencarelli F., 2004. Fennel. The Commercial Storage of Fruits, Vegetables, and Florist and Nursery Stocks. Agricultural Handbook Nr 66. USDA-ARS, Plant Sci. Instit., Beltsville: 2.

Michalik Ł., Szweykowska B., 2005. Wpływ metody uprawy i gęstości sadzenia rozsady na wielkość plonu selera naciowego. Zesz. Nauk. AR we Wrocławiu, LXXXVI, 515: 353-358.

Morales M.R., Charles D.J., Simon J.E., 1993. Fennel, a new specialty vegetable for the fresh market. In: J. Janick and J.E. Simon (eds), New crops. Wiley, New York 2: 576-579.

NAJDA A., 2004. Plonowanie i ocena fitochemiczna roślin w różnych fazach wzrostu dwu odmian selera naciowego (Apium graveolens L. var. dulce Mill./ Pers.). Rozpr. Doktor., AR w Lublinie.

PluciŃSKA M., 2001. Fenkuł - koper włoski warzywny (Foeniculum vulgare var. azoricum Miller). IW, Skierniewice: 5.

Rekowska E., 1997. The effect of soil mulching on the yield and quality of garlic developing inflorescence stalks. Folia Hort. 9(1): 59-65.

Rekowska E., SŁodkowski P., 2005. Wpływ płaskiego okrycia roślin oraz normy siewu nasion na plonowanie roszponki. Zesz. Nauk. AR we Wrocławiu, LXXXVI, 515: 433-439.

Rusch A., 2001. Welche Sorte bei Kopfsalat, Sommerzwiebel und Knollenfenchel? Ergebnisse aus Wadenswil/Schweiz. Gemüse München 37(11): 38-39.

Siwek P., LiBik A., 2005. Wpływ osłon z folii i włókniny w uprawie wczesnej selera naciowego na wielkość i jakość plonu. Zesz. Nauk. AR we Wrocławiu, LXXXVI, 515: 483-490.

UNECE 2005. Acceptances of UNECE standards. U.N. Economic Commission for Europe. Specialized
Section on Standardization of Fresh Fruit and Vegetables. 51st sess. Geneva 8-11 March 2005, TRADE/WP.7/GE.1/2005/ 17. 14 December 2005: 4.

VANPARYS L., 1999 a. Cultivar trial with fennel for early cultivation. Mededeling Prov. Onderzoek en Voorlichtingscentrum voor Land en Tuinbouw, Beitem Roeselare 405: 4.

Vanparys L., 1999 b. Fennel. Summer cultivation of fennel, Atos, Heracles, Goal and Match are the leaders! Proeftuinnieuws 9(5): 21-22.

Vogel G., 1987. Zum Einfluss gestaffelter Pflanztermine und unterschiedlicher Standweiten auf die Ertragsleitung von Knollenfenchel (Foeniculum vulgare var. azoricum Miller). Archiv. Gartenbau 35(1): 1-11.

WieRzBICKA B., 1999. Wpływ metody uprawy na plonowanie kilku odmian sałaty masłowej w polu. Zesz. Probl. Post. Nauk Roln. 466: 117-128.

WierzBickA B., 2002. Mniej znane rośliny warzywne. Wyd. UWM, Olsztyn: 26-27.

\section{WPŁYW OSŁANIANIA GLEBY I ROŚLIN ORAZ TERMINU SIEWU NA PLON ZGRUBIEŃ KOPRU WŁOSKIEGO UPRAWIANEGO Z SIEWU WPROST NA POLE}

Streszczenie: Doświadczenie polowe z uprawą kopru włoskiego (Foeniculum vulgare var. azoricum Mill.) przeprowadzono w Gospodarstwie Doświadczalnym UP w Lublinie na glebie płowej. Uwzględniono następujące czynniki: 3 rodzaje osłon - okrycie gleby czarną folią polietylenową (PE 0,15 mm), okrycie gleby czarną włókniną polipropylenową (PP $50 \mathrm{~g} \mathrm{~m}^{-2}$ ) i płaskie okrycie roślin białą włókniną polipropylenową (PP $17 \mathrm{~g}$ $\left.\mathrm{m}^{-2}\right) ; 3$ terminy siewu - kwiecień, maj, czerwiec; 2 odmiany - 'Rudy F ' i 'Zefa Fino'. Ściółkowanie gleby PP50 i w nieco mniejszym stopniu PE zwiększyło plon ogólny i handlowy zgrubień fenkułu oraz wpłynęło korzystnie na jego strukturę. Najmniejszy plon, $\mathrm{z}$ największym udziałem zgrubień niehandlowych, uzyskano po osłanianiu roślin PP17. Na obiektach ściółkowanych PP50 zgrubienia były największe. Najdrobniejsze zgrubienia zebrano po osłanianiu roślin PP17. Najkorzystniejszy dla fenkułu był siew wykonany w kwietniu. Najmniejszy plon otrzymano z siewów czerwcowych. Badane odmiany nie różniły się pod względem wielkości plonu i jego struktury. Zgrubienia odmiany 'Zefa Fino' były dłuższe i smuklejsze od zgrubień odmiany 'Rudy $F_{1}$ '.

Received March 8, 2010; accepted December 17, 2010 